\section{Kastamonu Eğitim Dergisi Kastamonu Education Journal}

Mart 2019 Cilt:27 Sayı:2

kefdergi.kastamonu.edu.tr
Başvuru Tarihi/Received: 06.03.2018

Kabul Tarihi/Accepted: 02.11.2018

DOI: $10.24106 /$ kefdergi.2767

\title{
Öğrenme Stratejileri Öğretiminin Öğretmen Adaylarının Akademik Başarılarına, Öğrenme Stratejilerine ve Öğrenme Sorunlarına Olan Etkisinin Belirlenmesi
}

\section{The Effect of Teaching Learning Strategies on Academic Achievement, Learning Strategies Used and Learning Problems of Pre-service Teachers" ${ }^{{ }_{1}}$}

\section{Öz}

\author{
Aysemin DURAN², Kemal Oğuz ER ${ }^{3}$
}

Bu çalışma öğrenme stratejileri öğretiminin öğretmen adaylarının akademik başarılarına, öğrenme stratejilerine ve öğrenme sorunlarına olan etkisini belirlemek amacıyla yapılmıştır. Araştırmada yarı deneysel desenlerden öntest-sontest kontrol gruplu desen kullanılarak; "Güdülenme ve Öğrenme Stratejileri Ölçeği" ve başarı testi ile nicel veriler; görüşme formları ile nitel veriler toplanmıştır. Yapılan görüşmeler, deneysel müdahale olarak ele alınmıştır. Araştırmanın amacı doğrultusunda, üç deney ve bir kontrol grubu belirlenerek, deneysel müdahaleden önce ve sonra deney ve kontrol gruplarına, "Güdülenme ve Öğrenme Stratejileri Ölçeği" ve başarı testi uygulanmıştr. Deney gruplarından birinde strateji öğretimi, birinde görüşme, bir diğerinde ise hem strateji öğretimi hem de görüşme gerçekleştirilmiştir. Görüşme verilerinin analizinde içerik analizi yöntemi, nicel verilerin analizinde ise varyans analizleri kullanıımıştır. Araştırma sonuçlarına göre, öğrenme stratejileri öğretiminin öğrenme sorunlarının azalmasına katkı sağladığı belirlenmiştir. Ayrıca öğrenme stratejileri öğretiminin öğretmen adaylarının strateji kullanmalarına etkisi yokken, başarı puanlarına olumlu etkisi olmuştur; ancak bu etki deney ya da kontrol grubunda bulunmaya göre birbirinden anlamlı fark göstermemiştir.

Anahtar Kelimeler: Öğrenme sorunları, öğrenme stratejilerinin öğretimi, öğretmen adaylarının akademik başarısı

\section{Abstract}

This study was conducted to determine the effects of teaching strategies on academic achievement, learning strategies and learning problems of pre-service teachers. Pretest-posttest control group design from quasi-experimental designs was used in the study. In line with the objective of the research, three experimental and one control group were identified and the "Motivation and Learning Strategies Scale" and achievement test were applied to experimental and control groups before and after experimental intervention. One of the experimental groups was applied strategy teaching, one was applied interview, and the other was applied both strategy teaching and interview and the interviews were considered as experimental intervention. Content analysis method was used for the analysis of interview data and variance analysis was used for the analysis of quantitative data. According to the results of the research, it has been determined that teaching of learning strategies contributes to decrease of learning problems. Moreover, while the teaching of learning strategies has no effect on pre-service teachers' strategy use, it has a positive effect on their achievement scores; but this effect did not differ significantly from each other in the experimental or control group.

Keywords: Learning problems, teaching learning strategies, academic achievement of pre-service teachers'

1. Bu çalışma, ilk yazarın "Öğrenme stratejileri öğretiminin öğretmen adaylarının akademik başarılarına, öğrenme güdülerine, kullandıkları öğrenme stratejilerine ve yürütücü bilişlerine olan etkisinin belirlenmesi” başlıklı doktora tezinden türetilmiştir.

2. İstanbul Okan Üniversitesi, Eğitim Fakültesi, Eğitim Bilimleri Bölümü, İstanbul, Türkiye, aysemin.duran@okan.edu.tr; https://orcid.org/0000-0003-4873-1120

3. Balıkesir Üniversitesi, Necatibey Eğitim Fakültesi, Eğitim Bilimleri Bölümü, Balıkesir, Türkiye, koer@gmail.com; https://orcid.org/0000-0001-6098-2067

Atıf / Citation: Duran, A., \& Er, K.O. (2019). Öğrenme stratejileri öğretiminin öğretmen adaylarının akademik başarılarına, öğrenme stratejilerine ve öğrenme sorunlarına olan etkisinin belirlenmesi.Kastamonu Education Journal, 27(2), 799-808. doi:10.24106/kefdergi.2767 


\section{Extended Summary}

What is desired to achieve during teaching is to provide students with skills to obtain and use information. Students need to acquire the ability to learn by themselves and to monitor their own learning in order to improve themselves (Dikbaş \& Hasırcı, 2007). Every individual uses unique ways for getting prepared for learning, learning and remembering (Fer, 2011). Therefore, individuals need to be aware of their own learning processes (Ekici, 2003). One of the factors affecting the learning process is learning strategies. Learning strategies are behaviours and processes that learners have and affect the coding process as well as each of the techniques that facilitate the self-learning of the individual (Özer, 2002; Weinstein \& Mayer, 1986). When students with low academic achievement are compared with those with high academic achievement, it is indicated that students with high academic achievement set specific learning goals for themselves and that they use more strategies in their learning (Zimmerman, Bonner \& Kovach, 1996, Zimmerman, 2008). In this context, the research basically aims to determine whether teaching strategies influence the academic achievement, learning strategies, and learning problems of pre-service teachers. In line with this main objective, answers to the following questions were sought:

1. What are the learning problems experienced by pre-service teachers?

2. Before the experimental intervention;

a. What are the learning strategies used by pre-service teachers?

b. What is the level of pre-service teachers' academic achievement?

3. What is the effect of experimental intervention on

a. The academic achievement of pre-service teachers?

b. The learning strategies used by pre-service teachers?

4. What is the effect of the teaching of learning strategies on the elimination of learning problems?

Pretest-posttest control group design from quasi-experimental designs was used in the research. Quantitative data was collected by means of "Motivation and Learning Strategies Scale" and achievement test and qualitative data was collected by means of interview forms before and after experimental intervention process. The interviews were considered as experimental intervention. Experimental intervention was carried out in the course "Teaching Principles and Methods" during the fall semester of 2014-2015 academic year. In line with the objective of the research, three experimental and one control group were identified. One of the experimental groups was applied strategy teaching, one was applied interview, and the other was applied both strategy teaching and interview. The "Motivation and Learning Strategies Scale" which is used for obtaining the data on the learning strategies used by pre-service teachers and their motivation levels, consists of 2 sub-scales which are motivation and learning strategies. MS consists of 6 factors while LSS consists of 9 factors. The Cronbach alpha coefficients of the factors range from 0.86 to 0.41 and the corrected item-total score correlations range from 0.19 to 0.66 . When adapting this scale, the psychometric properties of the scale were not considered again as the study group was similar to the group in this study. However, before and after the experimental intervention process, the scale was applied to pre-service teachers and the Cronbach alpha coefficients of the scale were calculated as 0.91 for the pre-test and 0.92 for the post-test. The achievement test, developed by the researcher and consisting of 40 items in total. to determine which substances will take place in the final test, those with item distinctiveness index of 0,30 or more and those with item difficulty index of 0,50-0,80 were selected (Baykul, 2010:373; Bayrakçeken, 2008:272). During the data analysis process, descriptive statistics were used to determine the learning strategies used by pre-service teachers; one-way analysis of variance was used for unrelated samples to determine whether the learning strategies they use varied according to their majors; descriptive statistics were used to determine their achievement before experimental intervention and a two-factor analysis of variance for mixed measures was used to determine the effect of teaching of learning strategies on the learning strategies used by pre-service teachers and their academic achievement. Content analysis was used to analyze interview texts.

The problems experienced by the pre-service teachers in Experiment 2( $\left.G_{d 2}\right)$ and Experiment $3\left(G_{d 3}\right)$ groups can be stated as inability to focus due to attention deficit, inability to manage time efficiently, low self-confidence and high anxiety level during the preliminary talks held at the beginning of the period, According to the data obtained from interviews, the pre-service teachers in Experiment $2\left(\mathrm{G}_{\mathrm{d} 2}\right)$ and Experiment $3\left(\mathrm{G}_{-\mathrm{d} 3}\right)$ groups stated that they used iteration strategies the most while they used searching for help strategies the least. No significant differences were found between the total scores of the learning strategies of the experimental or control groups before and after the experimental intervention $\left[F_{(3-132)}=359,86, p>, 01\right]$.

It was concluded that experimental intervention has no effect on the learning strategies used by pre-service teachers. There is a significant difference between the achievement scores of all pre-service teachers whether it is experimental or control group before and after experimental intervention $\left[F_{(1-132)}=78,97, p<, 01\right]$. However, although it is desirable that there is a significant difference between the achievement scores of the experimental and control groups, there was no significant difference between the achievement scores $\left[F_{(1-132)=} 98.47, p>, 01\right]$.

During the interviews held at the end of the period, pre-service teachers in Experiment $2\left(\mathrm{G}_{\mathrm{d} 2}\right)$ group talked about some processes such as decrease / increase in learning desires and grades, decrease / increase in focus problems, increase / decrease in interest in lectures, increase / decrease in desire to study, regular and effective study for exams as regards the change in the learning process. Besides, pre-service teachers in Experiment $3\left(\mathrm{G}_{\mathrm{d} 3}\right)$ group talked about increase / decrease in learning desires, the same level of desire for learning, increase / decrease of grade average, time management, willingness to do homework as regards the change in the learning process.

By looking at the results of this study, it can be said that in order for pre-service teachers to be able to effectively use the strategies of monitoring understanding, organizing and searching for help which they are less aware of, more emphasis should be given to the teaching of these strategies. To help students use different learning strategies, it may be appropriate for instructors to include more visual items such as concept maps, concept nets, mind maps in their classes.

| Kastamonu Eğitim Dergisi, 27(2), 2019| 


\section{Giriş}

Öğretim sürecinde ulaşımak istenen, bilgiye ulaşma ve onu kullanma becerileri kazandırmakttr. Bu süreç, öğretmenlerin belli bilgi ve becerilere sahip olmalarını zorunlu kılmıştır. Öğrencilere bilgilerin aktarılması, becerilerin öğretilmesi, davranışların kazandırılması öğretmenler tarafindan gerçekleştirildiği için öğretmenlik mesleği birçok nitelik ve yeterlik gerektirmektedir. Weinstein ve Mayer (1986)'ya göre, iyi bir öğretim, öğrencilere nasıl öğreneceğini, hatırlayacağını, düşüneceğini ve kendilerini nasıl güdüleyeceklerini öğretmeyi kapsar. Öğrencilerin kendilerini geliştirmeleri için kendi kendilerine öğrenmeleri ve öğrenmelerini izleme yeterliği kazanmaları gerekmektedir (Dikbaş \& Hasırcı, 2008). Öğretimin, öğretim programlarındaki konuları ve öğrencilerin bu konuları nasıl öğreneceklerini kapsayacak biçimde planlanıp uygulanması gereklidir. Öğrencilerin öğrenmeyi öğrenme ihtiyaçları, öğretmen tarafindan "öğrenmeyi öğretme" etkinlikleriyle karşılanabilir (Özer, 1998). Öğrenmeyi öğrenme, başarının ve yaşam boyu öğrenmenin anahtarı olarak görülmektedir. Özer (2008), öğrenenlerin hem kendi öğrenme özelliklerini tanıyarak hem de öğrenmede yararlanılan teknikleri bilip kullanarak öğrenmeyi öğrenebileceklerini belirtmektedir. Her birey, öğrenmeye hazırlanma, öğrenme ve hatılama süreçlerinde diğerlerinden farklı yollar kullanmaktadır (Fer, 2011). Bu sebeple, bireylerin kendi öğrenme süreçlerine ilişkin farkındalık kazanmaları gerekmektedir (Ekici, 2003). Öğrenme sürecini etkileyen etmenlerden biri de öğrenme stratejileridir. Öğrenme stratejileri, öğrenenlerin sahip oldukları ve kodlama sürecini etkileyen davranışları ve süreci olmakla birlikte bireyin kendi kendine öğrenmesini kolaylaştran tekniklerden her biridir (Özer, 2002; Weinstein \& Mayer, 1986). Bireyler öğrenme stratejilerini kullandıklarında öğrenilenler kalıcı hale gelmektedir. Bu sebeple öncelikle öğrenme stratejilerinin öğretiminin yapılması gerekmektedir (Senemoğlu, 2007). Öğrenme stratejilerinin etkin kullanımı, öğrencilerin akademik alandaki öğrenme çabalarının verimliliğini arttırmaktadır. Düşük akademik başarıya sahip öğrencilerle, yüksek akademik başarıya sahip öğrenciler karşılaştrıldığında başarısı yüksek öğrencilerin kendileri için özel öğrenme hedefleri koydukları, öğrenmeleri sırasında daha çok stratejiye yer verdikleri belirtilmektedir (Zimmerman, Bonner \& Kovach, 1996; Zimmerman, 2008). Akademik başarıda bireyin belirli bir akademik alanda elde ettiği bilgi-beceri düzeyi ile bu bilgiyi farklı şekillerde kullanabilme yeterliliği, akıl yürütme ve problem çözme becerisindeki yeterlilik düzeyi önemlidir (Pellegrino, Chudowsky \& Glaser, 2001; Akt: Aktan: 2012: 20). Öğrencilerde akademik başarının yükseltilebilmesi için, öğrenme stratejilerinin kullanımı özendirilmelidir. Bu bağlamda; araştırmanın temel amacı; öğrenme stratejileri öğretiminin öğretmen adaylarının akademik başarılarına, kullandıkları öğrenme stratejilerine ve öğrenme sorunlarına etkisinin olup olmadığını belirlemektir. Bu temel amaç doğrultusunda aşağıdaki sorulara yanıt aranmıştır:

1. Öğretmen adaylarının deneysel müdahaleden önce yaşadıkları öğrenme sorunları nelerdir?

2. Deneysel müdahaleden önce;

a. Öğretmen adaylarının kullandıkları öğrenme stratejileri nelerdir?

b. Öğretmen adaylarının akademik başarıları ne düzeydedir?

3. Deneysel müdahalenin;

a. Öğretmen adaylarının akademik başarıları üzerindeki etkisi nedir?

b. Öğretmen adaylarının kullandıkları öğrenme stratejileri üzerindeki etkisi nedir?

4. Öğrenme stratejileri öğretiminin öğrenme sorunlarının ortadan kaldırılması üzerindeki etkisi nedir?

\section{Yöntem}

\section{Araştırma Modeli}

Öğrenme stratejileri öğretiminin öğretmen adaylarının akademik başarılarına, kullandıkları öğrenme stratejilerine ve öğrenme sorunlarına etkisinin incelendiği bu çalışmada yarı-deneysel desenlerden öntest-sontest kontrol gruplu desen kullanılmıştr. Araştırmada "Güdülenme ve Öğrenme Stratejileri Ölçeği" ve başarı testi ile nicel veriler; görüşme formları ile nitel veriler toplanmıştır. Yapılan görüşmeler, deneysel müdahale kapsamında ele alınmıştır. Deneysel müdahaleden elde edilen veriler pozitivist bir yaklaşımla analiz edilerek bulgular yorumlanmıştır (Groat, 2013).

\section{Deneysel Müdahale Süreci}

Araştırmanın deneysel müdahale işlemi 2014-2015 eğitim-öğretim yılı güz döneminde "Öğretim İlke ve Yöntemleri" dersinde gerçekleştirilmiştir. Süreç 2014 yılııın Eylül ayında başlamış ve aynı yılın Kasım ayı sonunda tamamlanmıştır. Araştırmanın amacı doğrultusunda, üç deney ve bir kontrol grubu belirlenmiştir. Deneysel müdahaleden önce deney ve kontrol gruplarına, "Güdülenme ve Öğrenme Stratejileri Ölçeği" ve başarı testi öntest olarak uygulanmıştı. Başarı testinden ve ölçeklerden elde edilen sonuçlara göre deney ve kontrol gruplarının birbirine denk gruplar olduğu sonucuna ulaşılmıştr. Deney gruplarından birinde strateji öğretimi, birinde görüşme, bir diğerinde ise hem strateji öğretimi hem de görüşme gerçekleştirilmiştir. İki deney grubu ile yapılan görüşmeler dönem başında ve sonunda olmak üzere iki kez 
yapılmıştır. Deney ve kontrol grupları, Balıkesir Üniversitesi Necatibey Eğitim Fakültesinde "Öğretim Illke ve Yöntemleri" dersini almakta olan ikinci sınıf öğrencileri arasından belirlenmiştir. Dersi almakta olan gruplar içinden rastlantısal olarak seçilen Deney $1\left(G_{d 1}\right)$ grubu sadece strateji öğretiminin gerçekleştirildiği, Deney $2\left(G_{d 2}\right)$ grubu sadece görüşmelerin yapıldığı, Deney $3\left(G_{d 3}\right)$ grubu hem strateji öğretiminin hem de görüşmelerin yapıldığı grubu ifade etmektedir. Herhangi bir deneysel müdahalenin gerçekleştirilmediği grup ise kontrol grubudur $\left(G_{k}\right)$. Deney $1\left(G_{d 1}\right)$ grubu fen bilgisi öğretmenliği, Deney $2\left(G_{d 2}\right)$ grubu ilköğretim matematik öğretmenliği, Deney $3\left(G_{d 3}\right)$ grubu okul öncesi öğretmenliği, kontrol grubu $\left(G_{k}\right)$ ise sosyal bilgiler öğretmenliği anabilim dallarında öğrenim görmekte olan ikinci sınıf öğrencilerinden oluşmaktadır. Deney $1\left(G_{d 11}\right.$ grubunda 30, Deney $2\left(G_{d 2}\right)$ grubunda 36, Deney $3\left(G_{d 3}\right)$ grubunda 33, Kontrol grubunda $\left(G_{k}\right) 40$ olmak üzere toplamda 139 öğretmen adayından veri toplanmıştır.

\section{Veri Toplama Araç ve Teknikleri}

Deneysel işlem sürecinde gerçekleştirilecek öğretim için ders planları ve etkinlikler 2014 yılının Haziran- Ağustos aylarında hazırlanmıştır. Başarı testi ile beraber deneysel işlem öncesi ve sonrasında kullanılan ölçekler, 2014 yılının Eylül ve Aralık aylarında uygulanmıştı. Öğretmen adaylarıyla gerçekleştirilen strateji öğretiminin akademik başarıya etkisinin belirlenmesi amacıyla araştırmacı tarafindan hazırlanan başarı testi geliştirilmiştir.

\section{Görüşme Formu}

Deney grubu $2\left(\mathrm{G}_{\mathrm{d} 2}\right)$ ve deney grubu $3\left(\mathrm{G}_{\mathrm{d} 3}\right)$ 'te yer alan öğretmen adaylarına uygulanmak üzere araştırmacı tarafindan iki görüşme formu geliştirilmiştir. Bu formlardan; ön görüşme formu öğretmen adaylarının yaşadıkları öğrenme sorunlarının neler olduğu, kullandıkları öğrenme stratejilerinin farkında olup olmadıklarını yoklamaya dönük olarak nasıl ders çalıştkları, öğrenme sırasında karşılaşttkları sorunlarla nasıl başa çıktıklarının belirlenmesi amacıyla hazırlanmıştı. Son görüşme formu ise öğrenme stratejileri öğretiminin öğretmen adaylarında bir değişikliğe neden olup olmadığı, olduysa nasıl bir değişime neden olduğu, öğrenme isteklerinde bir değişiklik olup olmadığı, öğrenme stratejileri öğretiminin etkililiği ve öğrenme stratejileri öğretiminin daha farklı olarak nasıl yapılabileceğine dair sorulardan oluşmaktadır. Her iki görüşme formunun hazırlanma aşamasında sorular araştırmacı tarafindan oluşturulduktan sonra eğitim programları ve öğretim anabilim dalından üç öğretim üyesinden, rehberlik ve psikolojik danışmanlık anabilim dalından bir öğretim üyesinden, Türkçe eğitimi anabilim dalından bir öğretim elemanından olmak üzere sorularla ilgili görüşleri alınmıştr. Taslak görüşme formları üzerinde gelen öneriler doğrultusunda düzeltmeler yapıldıktan sonra 10 öğretmen adayı ile soruların açıklığını ve anlaşılırığını kontrol etmek amacıyla görüşme yapıımıştır. Bu görüşmeler sonrasında bazı sorular üzerinde ifade değişikliğine gidilmiş, soru sayısı arttrılmış ve görüşme formlarının son hali verilmiştir.

\section{Güdülenme ve Öğrenme Stratejileri Ölçeği}

Öğretmen adaylarının kullandıkları öğrenme stratejilerine ve güdülenme düzeylerine ilişkin verileri elde etmede Büyüköztürk ve diğerleri (2004) tarafindan Türkçe alanyazına kazandırılan “Güdülenme ve Öğrenme Stratejileri Ölçeği”nden izin alınarak yararlanılmıştır. Ölçek, "güdülenme" ve "öğrenme stratejileri”ne ilişkin önermelerden oluşmaktadır. Geçerlik ve güvenirlik çalışmalarında ölçeğin ayrı ayrı faktör analizleri ve güvenirlik çalışmaları gerçekleştirilmiştir. Bu bakımdan ölçeğin iki farklı ölçek gibi kullanılabileceği belirtilmiş ve bu çalışmada "Öğrenme Stratejileri" alt ölçeğinden faydalanılmıştır. GÖ alt faktörlü, ÖSÖ ise dokuz faktörlü bir yapıdan oluşmaktadır. Faktörlerin Cronbach alfa katsayıları 0.86 ile 0.41 arasında, düzeltilmiş madde-toplam puan korelasyonları 0.19 ile 0.66 arasında değişmektedir. $T$ testi sonuçları, üst \% 27 ile alt \% 27 grupların madde ortalamaları arasındaki tüm farkların anlamlı olduğunu göstermiştir. Türkçe form, eşdeğerlik çalışmasının ardından iki farklı üniversitede, farklı bölümlerde okuyan 852 üniversite öğrencisine uygulanmıştr. Yapılan analizler sonucunda toplam 81 maddeden oluşan ölçekte GÖ alt faktörlü, ÖsÖ ise dokuz faktörlü bir yapıdan oluşmaktadır. Faktörlerin Cronbach alfa katsayıları 0.86 ile 0.41 arasında, düzeltilmiş madde-toplam puan korelasyonları 0.19 ile 0.66 arasında değişmektedir. T testi sonuçları, üst \% 27 ile alt \% 27 grupların madde ortalamaları arasındaki tüm farkların anlamlı olduğunu göstermiştir.

Ölçek uyarlanırken çalışılan çalışma grubunun bu araştırmadaki grupla benzer özellikler gösteriyor olması sebebiyle ölçeğin psikometrik özelliklerine yeniden bakılmamıştı. Ancak, deneysel müdahale sürecinin öncesinde ve sonrasında ölçek öğretmen adaylarına uygulanmış ve ölçeğin Cronbach alpha katsayıları ön-test için 0.91 , son-test için 0.92 olarak hesaplanmıştr.

\section{Başarı Testi}

Başarı testi araştırmacı tarafindan 2014 yılının Nisan - Mayıs aylarında geliştirilmiş, Haziran ayında deneme testi olarak uygulanmış ve testin nihai formu oluşturulmuştur. Testin hazırlanma aşamaları şu şekilde gerçekleştirilmiştir: 
Öğretim Illke ve Yöntemleri dersi hedef-davranışları belirlenmiştir. Kapsam geçerliğinin sağlanması amacıyla belirtke tablosu oluşturularak dersin hedef davranışlarını kapsayacak biçimde maddeler oluşturulmuştur. Her bir hedef davranışla ilgili olacak şekilde en az 2 soru olmak üzere sorular hazırlanmış ve dört ayrı deneme testi oluşturulmuştur. Deneme testleri Öğretim İlke ve Yöntemleri dersini almış olan Necatibey Eğitim Fakültesi dördüncü sınıflarında öğrenim gören toplam 650 öğrenciye uygulanmıştr. Birinci deneme testinde 42 Öğretim Illke ve Yöntemleri, ikinci deneme testinde 45 Öğretim Illke ve Yöntemleri, üçüncü deneme testinde 36 Program Geliştirme ve Öğretim, dördüncü deneme testinde 38 Program Geliştirme ve Öğretim maddesi yer almaktadır. Deneme testleri uygulaması bitiminde nihai test formunu oluşturmak amacıyla maddelerin güçlük ve ayırt edicilik indeksleri hesaplanmıştr. Hangi maddelerin nihai testte yer alacağına madde ayırt edicilik indeksi 0,30 ve üzerinde olanlar; madde güçlük indeksi 0,50-0,80 aralığında olanlar seçilerek karar verilmiştir (Baykul, 2010:373; Bayrakçeken, 2008:272). Nihai testte 22 öğretim ilke ve yöntemleri, 18 program geliştirme ve öğretim maddesi yer almaktadır. Testin KR-20 güvenirlik katsayısı 0,81 olarak hesaplanmıştr. Toplamda 40 maddeden oluşan başarı testi 2014-2015 eğitim-öğretim yılı güz dönemi başında ve sonunda deney ve kontrol gruplarına uygulanmıştir.

\section{Verilerin Analizi}

Veri girişine başlamadan önce ölçeklerdeki öğrenci isimlerine numaralar verilerek, deneysel işlem öncesi ve sonrasında aynı öğrenciler ile çalışılıştır. Veri kaybını önlemek amacıyla deneysel işlem öncesinde katılım sağlayan öğrencilere deneysel işlem sonrasında da yapılan numaralandırma sayesinde ulaşımıştır. Öğretmen adaylarının kullandıkları öğrenme stratejilerinin belirlenmesi için görüşme verilerinden; deneysel müdahale öncesi başarılarının belirlenmesi için betimleyici istatistiklerden; öğrenme stratejileri öğretiminin öğretmen adaylarının kullandıkları öğrenme stratejilerine ve akademik başarılarına olan etkisinin belirlenmesi için karışı ölçümler için iki faktörlü varyans analizinden yararlanılmıştır.

Araştırmanın nitel verilerinin çözümlenmesinde öncelikle öğrencilerin ses kayıtları yazılı metne dökülmüştür. Görüşme metinlerinin analizinde içerik analizi benimsenmiştir. İçerik analizinde, önceden toplanan veriler kavramsallaştrılarak, ortaya çıkan kavramlar temalar haline dönüştürülür (Yıldırım \& Şimşek, 2008:227). Görüşme metinlerinin analizinde izlenen yol aşağıdaki gibidir:

Öncelikle tüm öğretmen adaylarının izni alınarak ses kayıtları gerçekleştirilmiştir. Veri analizi sürecinde; araştırmacı tarafindan ses kayıtları dikkatlice dinlenerek yazıya geçirilmiştir. Görüşme yapılan öğretmen adayının tüm söyledikleri eksiksiz bir biçimde aktarılmıştı. Tüm ses kayıtları metne döküldükten sonra kodlama sürecine geçmeden araştrrmacı tarafindan birkaç kez okunmuştur. Verilerin kodlanması sürecinde kodlamanın yapılması ve ortaya çıkan kodlar üzerinde tekrar tekrar çalışılması gerekmektedir (Yıldııı \& Şimşek, 2008:229). Daha sonra kodlama anahtarı oluşturularak mikro analizler yapılmıştır. Temalar ve alt temalar oluşturulduktan sonra eğitim programları ve öğretim alanındaki bir öğretim elemanından görüş birliğinin sağlanması amacıyla kontrol-kodlaması yapması istenmiştir. Metinlerin 10 sayfalık bir kısmı öğretim elemanına verilmiş, kodlama yaptıktan sonra her biri araştırmacı ile birlikte gözden geçirilmiştir. Miles ve Huberman'a göre $(1994 ; 64)$ kontrol-kodlaması ortaya çıkan tanımların netliğini sağlamakla birlikte iyi bir güvenirlik kontrolüne de yardımcı olur. íki kodlayııı arasındaki güvenirlik katsayısı aşağıdaki formülle hesaplanmaktadır ve önerilen \%80'in üzerinde çıkmasıdır

Güvenirlik= (Görüş birliği sayısı / Toplam görüş birliği + Görüş ayrılığı sayısı) * 100

Bu formüle göre;

Güvenirlik= $(93 / 93+25) * 100=\% 78$ olarak hesaplanmıştır.

Bu sonuca göre, yapılan kodlamaların güvenilir olduğu sonucuna ulaşılımıştır (Yıldırım \& Şimşek, 2008; Miles \& Huberman, 1994). Bulunan ortak temalar araştırmanın alt problemlerinin bulguları olarak değerlendirilmiştir.

\section{Bulgular ve Yorumlar}

Öğretmen adaylarının yaşadıkları öğrenme sorunlarının belirlenmesi amacıyla Deney $2\left(G_{d 2}\right)$ grubu ve Deney $3\left(G_{d 3}\right)$ grubunda yer alan öğretmen adayları ile 2014-2015 güz döneminin başında yapılan ön görüşmelerde, öğretmen adaylarına hangi öğrenme stratejilerini kullandıkları, öğrenme sürecinde ne gibi zorluklar yaşadıkları ve bu sorunlarla başa çıkmak için neler yaptıkları sorulmuştur. Elde edilen veriler neticesinde "öğrenme sürecindeki zorluklar" teması belirlenmiştir. Deney $2\left(\mathrm{G}_{\mathrm{d} 2}\right)$ grubunda yer alan toplam otuz alt(36) öğrenciden yirmi(20) öğrenci öğrenme sürecinde zorluk yaşadığını ifade etmiştir. Bu zorluklar; yüksek düzeyde kaygı, dikkat dağınıklığı, odaklanma sorunu, sözel derslere karşı olumsuz tutum, zaman yönetiminde sıkınt, düşük özgüven, konular/dersler arası ilişkilendirmeleri yapamama olarak 
belirtilmiştir:

M40:...Tam odaklanmadıysam anlayamam zaten. Odaklanma problemim oluyor. Yani mesela derse başlamadan şunu da yapayım bunu da yapayım. Ya da derse başlamadan aklıma bir şey geliyor, onu da yapayım diye kalkıyorum. Ya da soruyu çözerken aklıma bir şey geliyorsa anında onu düşünmeye başlıyorum. Dikkatim dağılıyor. Her zaman düzenli çalışmayı oturtamıyorum. Birkaç hafta birikiyor bazen...

Deney $3\left(G_{d 3}\right)$ grubunda yer alan toplam otuz üç(33) öğrenciden on yedi(17) öğrenci öğrenme sürecinde sorun yaşadıklarını belirtmişlerdir. Bu sorunlar; dikkat dağınıklığı, zaman yönetiminde sıkınt, özgüven düşüklüğü, odaklanamama, öğretim elemanına karşı önyargılı olma, yüksek kaygı, nasıl özet çıkaracağını bilmeme olarak ifade edilmiştir:

010: ...Orada yazan şeyi anlıyorum ama ifade edemiyorum. O beni biraz sıkıntıya sokuyor. Aynısı olsun diye ezberlemeye çalışıyorum. Dikkatim dağılıyor bir süre sonra aynı şekilde çalışamıyorum. Arada düşüncelere dalıyorum falan.

O23: Dinliyorum hocayı, çok iyi dinliyorum. Ama sonra aklıma başka yere gidiyor ya da anlatthğı şeyden başka bir şeye gidiyorum ben. Kopuyorum yani.

Öğretmen adaylarının kullandıkları öğrenme stratejilerinin neler olduğunun belirlenmesi amacıyla görüşmelerden elde edilen verilere göre Deney $2\left(G_{\mathrm{d} 2}\right)$ grubunda yer alan otuz alt (36) öğrencinin en çok kullandıkları stratejilerin yineleme stratejileri olduğu ortaya çıkmıştı. Buna göre yirmi(20) öğrenci not almayı, on dört(14) öğrenci metin okurken renkli kalemler kullandıklarını belirtmiştir:

M4: Yazarak çalışmayı severim...Önemli gördüğüm yerleri not olarak çıkartırım zaten. Fosforlu kalem kullanırım not alırken.

M12: ...Hoca ders anlatırken kitabın üstüne not alıyorum...Küçük kağıtlarım var not aldığım yerlere onları yapıştırıyorum. Fosforlu kalemlerle yazıyorum veya notlar çıkarıyorum.

Deney $3\left(G_{d 3}\right)$ grubunda yer alan otuz üç (33) öğrencinin ifadelerine göre en fazla yineleme stratejilerini kullanmaktadırlar. Ayrıca bir öğrencinin birden fazla öğrenme stratejisini bir arada kullandığı da görülmektedir. Yirmi dört (24) öğrenci yineleme stratejilerinden aynı sözcüklerle not almayı kullandığını, on iki (12) öğrenci öğrenme amacıyla tekrarlar yaptığını, on üç (13) öğrenci metinleri okurken renkli kalemleri kullandığını belirtmiştir:

O4: ...Sizin söylediklerinizden kitapta olanların altını çizdim. Kitabın yanına mavi boşluk bırakmışlar. Diğerlerini de oraya yazıyorum. En belirgin olanlarını not alıyorum.

014: Çok severim. Fosforlu kalemler böyle. Kitabımı açtğımda zaten her yer çizilidir böyle. Öyle seviyorum.

Deneysel müdahaleden önce öğretmen adaylarının kullandıkları öğrenme stratejilerinin belirlenmesi amacıyla yapılan görüşmeler sonucunda; Deney $2\left(G_{d 2}\right)$ ve Deney $3\left(G_{d 3}\right)$ grubunda yer alan öğretmen adayları en çok yineleme stratejilerini, en az ise yardım arama stratejilerini kullandıklarını ifade etmiştir.

“Güdülenme ve Öğrenme Stratejileri Ölçeği"nden elde edilen verilere göre ise öğretmen adaylarının $\bar{X}=5,25$ ortalama ile en çok açımlama stratejilerini, en az ise $\bar{X}=4,81$ ortalama ile yardım arama stratejilerini kullandıkları görülmektedir. Görüşme verileri ile ölçekten elde edilen veriler karşılaştırıldığında, en çok kullanılan öğrenme stratejilerinde farklılık olduğu görülmektedir.

Öğretmen adaylarına deneysel müdahale süreci başlamadan önce akademik başarı düzeylerinin belirlenmesi amacıyla başarı testi uygulanmıştır.

Tablo 1. Öğretmen adaylarının deneysel müdahale öncesi akademik başarılarına ilişkin betimsel istatistikler

\begin{tabular}{cccc}
\hline & $\mathrm{N}$ & $\overline{\mathrm{X}}$ & SS \\
\hline Başarı Düzeyi & 136 & 33,83 & 7,80 \\
\hline
\end{tabular}

Öğretmen adaylarına, deneysel müdahale süreci başlamadan önce uygulanan başarı testinden aldıkları puanların $\bar{X}=33,83$ olarak bulunmuştur. Bu sonuca göre öğrencilerin deneysel müdahale öncesindeki akademik başarılarının düşük düzeyde olduğu sonucuna ulaşılabilir.

Deneysel müdahalenin, öğretmen adaylarının başarısı ve kullandıkları öğrenme stratejileri üzerindeki etkisinin belirlenmesi amacıyla tekrarlı ölçümler için varyans analizi yapılmıştır. 
Tablo 2. Deneysel müdahalenin deney grupları ve kontrol grubunun akademik başarısına etkisine ilişkin tekrarlı ölçümler için varyans analizi sonuçları

\begin{tabular}{lccccc}
\hline Varyansın kaynağı & KT & sd & KO & F & p \\
\hline Deneklerarası & 9583,173 & 135 & & & \\
Grup (Birey/Grup) & 1898,280 & 3 & 632,760 & 10,869 &, 000 \\
Hata & 7684,893 & 132 & 58,219 & & \\
Denekleriçi & 13388.565 & 136 & & &, 000 \\
Ölçüm (Öntest-Sontest) & 4901,656 & 1 & 4901,656 & 78,987 &, 196 \\
Grup*Ölçüm & 295,420 & 3 & 98,473 & 1,587 & \\
Hata & 8191,489 & 132 & 62,057 & & \\
Toplam & 22971,738 & 271 & & & \\
\hline
\end{tabular}

Deneysel müdahale sonrasında deney ya da kontrol grubu ayrımı yapılmaksızın tüm öğretmen adaylarının başarı puanları arasında anlamlı fark bulunmuştur $\left[F_{(1,132)}=78,97, p<, 01\right]$. Araştırmada, deney ve kontrol gruplarının başarı puanları arasında anlamlı fark olması arzu edilmekle birlikte deney ve kontrol gruplarının başarı puanları arasında anlamlı bir farklılığa rastlanmamıştır $\left[\mathrm{F}_{(3,132)=} 98,47, \mathrm{p}>, 01\right]$.

Deneysel müdahalenin kullanılan öğrenme stratejileri üzerindeki etkisinin belirlenmesi amacıyla tekrarlı ölçümler için varyans analizi yapılmıştır.

Tablo 3. Deneysel müdahalenin deney grupları ve kontrol grubunun kullandığı öğrenme stratejilerine etkisine ilişkin karışık ölçümler için varyans analizi sonuçları

\begin{tabular}{lccccc}
\hline Varyansın kaynağı & KT & sd & KO & F & p \\
\hline Deneklerarası & 75047,236 & 135 & & & \\
Grup (Birey/Grup) & 1079,604 & 3 & 359,868 &, 642 &, 589 \\
Hata & 73967,632 & 132 & 560,361 & & \\
Denekleriçi & 75153.559 & 136 & &, 190 &, 664 \\
Ölçüm (Öntest-Sontest) & 106,323 & 1 & 106,323 &, 642 & \\
Grup* Ölçüm & 1079,604 & 3 & 359,868 & \\
Hata & 73967,632 & 132 & 560,361 & & \\
Toplam & 150200,795 & 271 & & & \\
\hline
\end{tabular}

Deneysel müdahale sonrasında deney ya da kontrol gruplarının öğrenme stratejileri toplam puanları arasında anlamlı herhangi bir farklılığa rastlanmamıştır $\left[F_{(3,132)}=359,86, p>, 01\right]$. Yani, deneysel müdahalenin deney gruplarının kullandığı öğrenme stratejileri üzerinde bir etkisi olmamıştır. Bununla birlikte; deney ve kontrol gruplarının deneysel müdahale öncesi ve sonrasında hangi öğrenme stratejilerini kullandıklarının belirlenmesi amacıyla betimsel istatistiklerine bakılmıştr. Güdülenme ve Öğrenme Stratejileri Ölçeği son testinden elde edilen verilere göre öğretmen adaylarının $\bar{X}=5,44$ ortalama ile en çok örgütleme stratejilerini, $\bar{X}=4,69$ ortalama ile en az yardım arama stratejilerini kullandıkları görülmektedir. Ön testlerden elde edilen verilere göre öğretmen adayları en çok açımlama, en az yardım arama stratejilerini kullanırken; son testlerden elde edilen verilere göre en çok örgütleme, en az yardım arama stratejilerini kullanmaktadırlar.

Gerçekleştirilen deneysel müdahalelerin, öğrenme sorunlarının ortadan kaldırılmasına etkisinin olup olmadığının belirlenmesi amacıyla deney $2\left(G_{d 2}\right)$ grubu ve deney $3\left(G_{d 3}\right)$ grubunda yer alan öğretmen adaylarıyla 2014-2015 güz dönemi sonunda görüşmeler yapılmıştır. Öğrenme stratejileri öğretimi yapılmayan deney $2\left(G_{d 2}\right)$ grubunda yer alan toplam otuz alt (36) öğrenciden on yedi(17) öğrenci öğrenme stratejilerinde herhangi bir değişikliğe gitmediğini, on dokuz (19) öğrenci ise ya öğrenme stratejilerini değiştirdiklerini ya da yeni öğrenme stratejilerini kullanmaya başladıklarını belirtmiştir:

M1: Matematik derslerimiz bizim biraz daha kötüydü. Şimdi daha iyi mesela. Çünkü yazmaya yönelik birisiydim. Hani yazayım illa özet çıkarayım falan. Onun yerine tam tersi maddeleyerek ve not alarak işte belirterek, derecelendirerek o şekilde daha iyi öğrendiğimi fark ettim.

M8: ...Ben bireysel çalışmayı daha çok seviyorum. Ama mesela iyi olan arkadaşlardan bir tanesiyle şey yapıyorduk biz. Soruları çözüyorduk. Haberleşiyorduk mesela ben şuraya kadar geldim. $\mathrm{O}$ diyor ben buraya kadar geldim. Kendimize müsait bir ortam bulup orada buluşup notlarımızı karşılaştırıyorduk. İkimiz de birbirimizin eksiklerini tamamlıyorduk mesela. Bunca yıllık bireysel çalışmanın üstüne böyle bir çalışmaya 
geçmem benim için daha iyi oldu...

Öğrenme stratejileri öğretimi yapılan Deney $3\left(G_{d 3}\right)$ grubunda yer alan toplam otuz üç (33) öğrenciden on sekiz (18) öğrenci öğrenme stratejilerinde değişiklik yaptıklarını, on beş (15) öğrenci ise aynı öğrenme stratejilerini kullanmaya devam ettiklerini belirtmiştir:

01: ...Dediğim gibi önce kavram haritası daha çok girdi. Diğer türlü de hani ımm daha böyle sessiz ortamları tercih ettiğimi fark ettim. Önceden daha fazla etkilenmediğimi düşünüyordum ama etkiliyormuş. Mümkün olduğunca sessiz ve hani bireysel çalışmaya daha fazla yöneldim. Eğer bir konu hakkında fazla bilgim yoksa önce kendim okuyorum.

016: ...Mesela ben önceden hepsinin altını çiziyordum. Şimdi hani önemli gördüğüm yerleri, aklımda kalacak yerlerin altını, ipuçlarının altını çiziyorum o şekilde. Bu şekilde daha verimli oluyor. Sonra dönüp baktığımda o altını çizdiğim kelimeler sınavda çıktığında aklıma geliyor.

Deney $2\left(G_{d 2}\right)$ grubunda yer alan öğretmen adayları dönem başında yapılan ön görüşmeden dönem sonunda yapılan son görüşmeye kadar öğrenme süreçlerinde meydana gelen değişimle ilgili olarak öğrenme isteklerinde ve notlarında azalma/artma, odaklanma sorunlarında azalma/artma, derslere olan ilginin artması/azalması, çalışma isteğinde artma/ azalma, sınavlara düzenli ve etkili çalışma gibi bazı süreçler olduğundan bahsetmişlerdir:

M8: ...kredisi yüksek derslerimizde falan sınav akşamlarında inanın ki çok rahatım. Defter tekrarını bitirmiş oluyorum. Şöyle defteri okuyorum bir kere. $\mathrm{O}$ akşam tv, bilgisayara çok odaklanamıyorum. Çünkü gözlerimi çok yoruyor. $\mathrm{O}$ akşam rahat oluyorum. Ertesi gün sınava geldiğimde rahat oluyorum inanın ki notlarım da yükseldi. Ciddi anlamda o sınav kaygısını attım.

M34: ...ileride mesleğimizle alakalı nasıl olabilir, nasıl öğretmen olabiliriz diye elbette bir şeyler öğrendik. Ama işte yoğunluktan dolayı bu dönem çok da çalışamadık. Notları düşürebiliriz yani gerçekten.

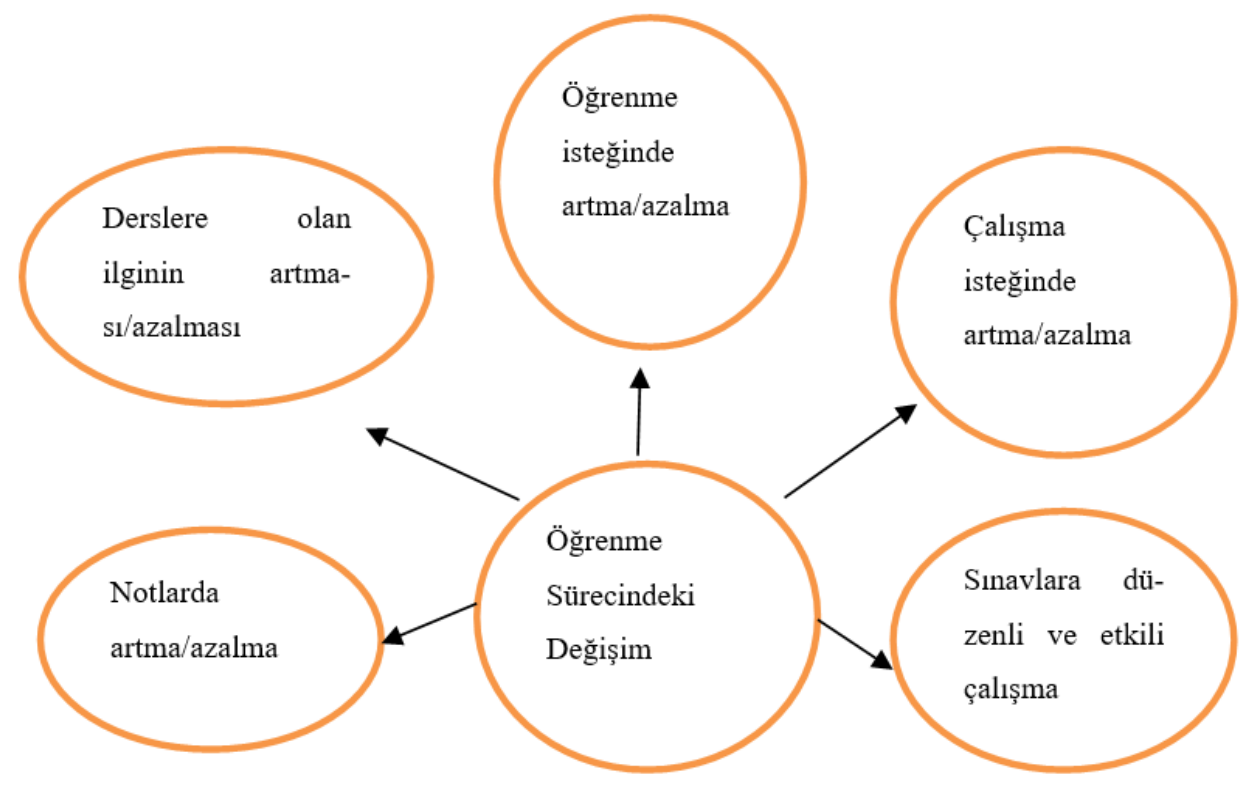

Şekil 1: Deney $2\left(G_{\mathrm{d} 2}\right)$ grubunda yer alan öğretmen adaylarının öğrenme süreçlerinde meydana gelen değişimler

Deney $3\left(G_{d 3}\right)$ grubunda yer alan öğretmen adayları ise dönem sonunda yapılan görüşmelerde öğrenme süreçlerinde meydana gelen değişikliklerle ilgili olarak öğrenme isteklerinin artması/azalması, öğrenme isteklerinin aynı kalması, not ortalamalarının yükselmesi/düşmesi, zaman yönetimini gerçekleştirme, ödev yapmada isteklilik olduğundan bahsetmişlerdir:

O27: ...Ben bu dönem içinde daha yüksek not aldım. Bu beni daha da güdüledi mesela. Daha iyi yapabiliyorum demek ki dedim. Bundan daha iyi yapmalıyım diye bir şey oldu yani. Şu an daha çok çalışmak, daha yüksek almak istiyorum.

013: ...hani geçen seneden bu sene daha rahatız. Hocalarımızı tanıdığımızdan dolayı da. Birbirimize karşı nasıl davranmamız gerektiğini biliyoruz en azından. Ödevlerle ilgili olsun daha irtibattaydık, o yüzden zorlanmadık bu sene. Daha istekli olarak ödevlerimizi yapıyoruz. 


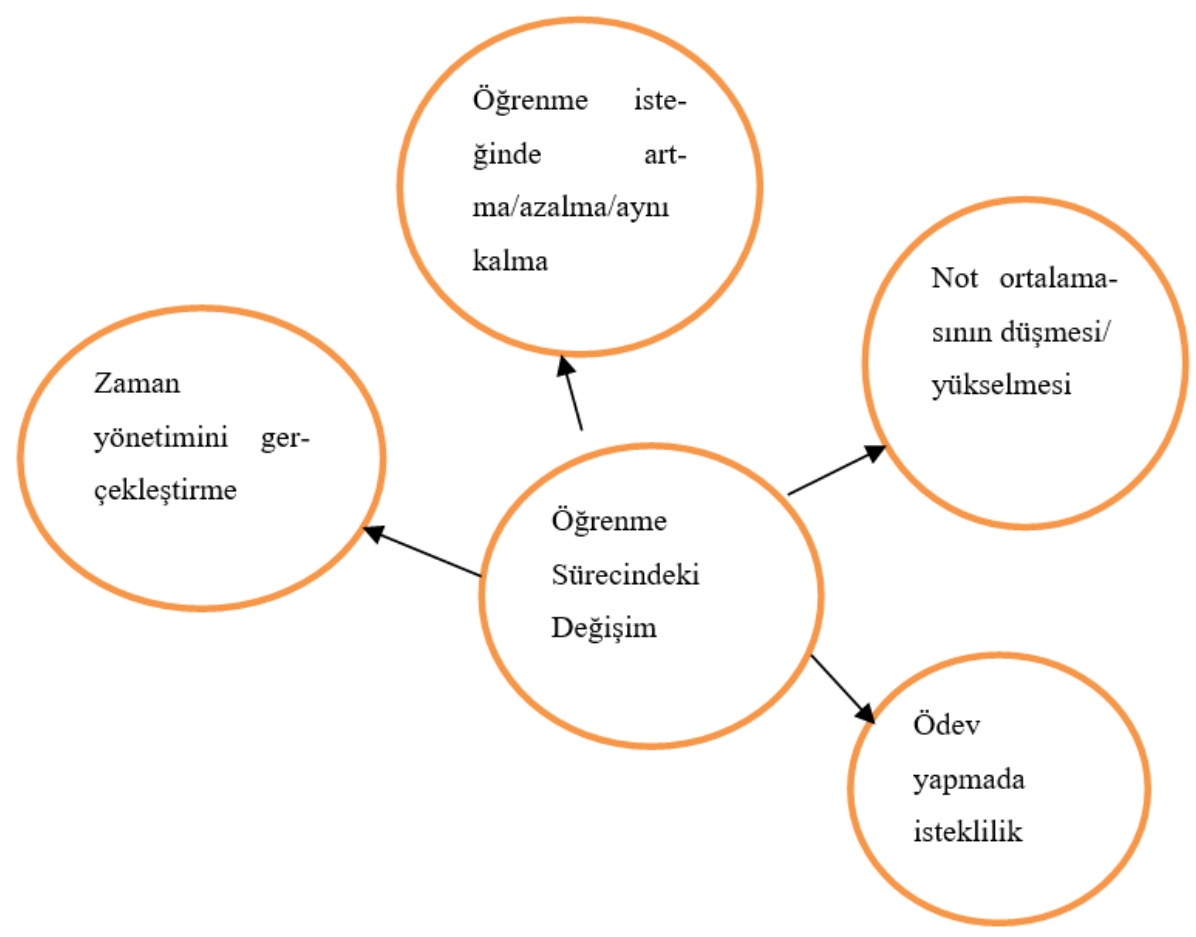

Şekil 2: Deney $3\left(G_{d 3}\right)$ grubunda yer alan öğretmen adaylarının öğrenme süreçlerindeki değişim

\section{Tartışma}

$\mathrm{Bu}$ araştırma kapsamında yapılan görüşmelerden elde edilen bulgulara göre, deney gruplarında $\left(\mathrm{G}_{\mathrm{d} 2}\right.$ ve $\left.\mathrm{G}_{\mathrm{d} 3}\right)$ gerçekleştirilen deneysel müdahalelerin (strateji öğretimi, görüşmeler) öğretmen adaylarının dönem içerisinde öğrenme sorunlarının azalmasına katkı sağladığı söylenebilir.

Araştırma sonuçlarına göre, öğretmen adaylarının dönem başında uygulanan başarı testinden elde ettikleri puanların aritmetik ortalamalarına bakıldığında akademik başarı düzeyleri düşük olarak bulunmuştur. Dönem başında yapılan görüşmelerden ve uygulanan ölçekten çıkarılan sonuçlara göre öğretmen adayları en çok açımlama ve yineleme stratejilerini, en az ise yardım arama stratejilerini kullanmaktadırlar. Dönem sonundaki uygulamalardan çıkarılan sonuçlara göre ise öğretmen adaylarııın en fazla örgütleme, en az ise yardım arama stratejilerini kullanmaktadırlar. Bu durumda, dönem başından dönem sonuna kadar öğretmen adaylarının kullandıkları öğrenme stratejilerinin farklılaştı̆̆ı söylenebilir. Duman, 2014 yılında yaptığı çalışmasında matematik öğretmenliği öğrencilerinin en çok anlamlandırma ve tekrar stratejilerini kullandıklarını ortaya koymuştur. Şahin ve Uyar (2013), eğitim fakültesi öğrencilerinin kullandıkları öğrenme stratejilerini belirlemeyi amaçladıkları çalışmalarında, öğrencilerin \%41 oranında tekrar, \%23 oranında anlamlandırma, $\% 20$ oranında dikkat, $\% 8$ oranında üst bilişsel, $\% 6$ oranında duyuşsal, \%2 oranında hatırlama stratejilerini kullandıklarını bulmuştur. Bu araştırmalardan elde edilen sonuçlar ile çalışmadan elde edilen sonuçların birbirine benzediği söylenebilir. Gerçekleştirilen deneysel müdahalelerin öğretmen adaylarının kullandıkları öğrenme stratejileri üzerinde anlamlı herhangi bir etkisi olmazken, başarı puanları üzerinde etkili olmuştur. Ancak bu etki, öğretmen adaylarının deney ve kontrol gruplarında yer almasına göre birbirinden anlamlı bir şekilde farklılaşmamaktadır. Yani gerçekleştirilen deneysel müdahalelerin deney gruplarının puanları üzerinde bir etkisi olmamıştr. Taşdemir ve Tay (2007) üniversite öğrencilerinin kullandıkları öğrenme stratejileri ile akademik başarıları arasındaki ilişkiye baktıkları deneysel çalışmada, öğrencilerin başarı öntest-sontest puanları arasında fark bulmuşlardır. Ortaya çıkan farkın, deney ve kontrol grubu açısından karşılaştııılığında deney grubu lehine olduğu ortaya çıkmıştır. Baykan, Naçar ve Mazıcıoğlu (2007)'nin de yaptıkları çalışmada, öğrenme stratejilerini etkili kullanan üniversite öğrencilerinin daha başarılı olduğu sonucuna ulaşılmıştır. Diğer çalışmaların sonuçları ile bu çalışmanın bulguları arasındaki farklılıkların; bu çalışma kapsamında yer alan deney ve kontrol gruplarının birbirine oldukça denk gruplar olmasından kaynaklandığı şeklinde düşünülebilir.

Bu çalışmanın bulgularından yola çıkarak; öğretmen adaylarının daha az farkında oldukları öğrenme stratejisi türlerinden anlamayı izleme, örgütleme ve yardım arama stratejilerini etkili olarak kullanabilmeleri için bu stratejilerin öğretimine daha fazla ağırlık verilebilir. Öğretim elemanlarının öğrencilerin farklı öğrenme stratejilerini kullanmalarına katkı sağlayabilmek için derslerinde kavram haritaları, kavram ağları, zihin haritaları gibi daha fazla görsel öğeye yer verme- 
leri yerinde olabilir ve ayrıca öğrenme stratejilerinin öğretimi ile ilgili deneysel çalışmalara daha fazla ağırlık verilebilir.

\section{Kaynakça}

Aktan, S. (2012). Öğrencilerin akademik başarısı, öz düzenleme becerisi, motivasyonu ve öğretmenlerin öğretim stilleri arasındaki ilişki. (Yayımlanmamış Doktora Tezi). Balıkesir Üniversitesi, Balıkesir.

Baykan, Z., Naçar, M. \& Mazıcıŏ̆lu,M. (2007). Öğrenme stratejilerinin öğrenci başarısına etkisi. Erciyes Tıp Dergisi (Erciyes Medical Journal), 29 (3), 220-227.

Baykul, Y. (2010). Eğitimde ve psikolojide ölçme: Klasik test teorisi ve uygulaması (2.Baskı). Ankara: Pegem Akademi.

Bayrakçeken, S. (2008). Test geliştirme. İçinde E. Karip (Ed.), Ölçme ve değerlendirme (ss: 243-274). Ankara: Pegem Akademi.

Büyüköztürk, Ş., Akgün, Ö. E., Demirel, F. \& Özkahveci, Ö. (2004). Güdülenme ve öğrenme stratejileri ölçeğinin Türkçe formunun geçerlik ve güvenirlik çalışması. Kuram ve Uygulamada Eğitim Bilimleri, 4(2), 207-239.

Dikbaş, Y., Hasırcı, K. Ö. (2008). Öğrenme stratejileri öğretiminin ve ders işlenişinde kullanımının öğrencilerin akademik başarılarına ve tutumlarına etkisi. Ahi Evran Üniversitesi Kırşehir Eğitim Fakültesi Dergisi (KEFAD), 9 (2), 69-76.

Duman, B. (2014). Matematik öğretmeni adaylarının öğrenme stratejileri üzerine nitel bir çalışma. Bartın Üniversitesi Eğitim Fakültesi Dergisi, 2014(2), 110-131.

Ekici, G. (2003). Öğrenme stiline dayalı öğretim ve biyoloji dersi öğretimine yönelik ders planı örnekleri. Ankara: Gazi Kitabevi.

Fer, S. (2011). Öğrenme stilleri ve stil odaklı öğretim tasarımı. İçinde S. Fer (Ed.), Öğrenme öğretme kuram ve yaklaşımları (ss: 203-205). Ankara: Anı Yayıncılık.

Groat, L. (2013). Case studies and combined strategies. In L. N.Groat \& D. Wang (Eds.), Architectural research methods (pp: 415-423). New Jersey: John Wiley \& Sons, Inc.

Miles, B. M., Huberman, A. M. (2015). Nitel veri analizi (Çev. Altun,S.A. ve Ersoy,A. ve diğerleri). Ankara, Pegem Akademi (Eserin orijinali 1994 'te yayımlandı).

Özer, B. (1998). Öğrenmeyi öğretme. İçinde A. Hakan (Ed.) Eğitim bilimlerinde yenilikler (ss: 147-164). Eskişehir: Anadolu Üniversitesi Açıöğretim Fakültesi.

Özer, B. (2002). illköğretim ve ortaöğretim okullarının eğitim programlarında öğrenme stratejileri. Eğitim Bilimleri ve Uygulama, 1(1), 17-32.

Özer, B. (2008). Öğrencilere öğrenmeyi öğretme. İçinde A. Hakan (Ed.), Öğretmenlik meslek bilgisi alanındaki gelişmeler (ss: 139-152). Eskişehir: Anadolu Üniversitesi Açıköğretim Fakültesi.

Senemoğlu, N. (2007). Gelişim, öğrenme ve öğretim. Ankara: Gönül Yayıncılık.

Şahin, H., Uyar, M.(2013). Öğrenme stratejileri kullanımının akademik başarıya yansımaları. Abant İzzet Baysal Üniversitesi Eğitim Fakültesi Dergisi,13(1), 164-177.

Taşdemir, A. , Tay, B. (2007). Fen bilgisi öğretiminde öğrencilerin öğrenme stratejilerini kullanmalarının akademik başarıya etkileri, Uludağ Üniversitesi Eğitim Fakültesi Dergisi, XX (1),173-187.

Weinstein, C. E., Mayer, R. E. (1986). The teaching of learning strategies. In M. C. Wittrock (Ed.). Handbook of Research on Teaching (pp: 315-327). New York: Macmillan.

Yıldırım, A., Şimşek,H. (2008). Sosyal bilimlerde nitel araştırma yöntemleri (6. Baskı). Ankara: Seçkin Yayıncılık.

Zimmerman, B.J., Bonner S., \& Kovach R. (1996). Developing self-regulated learner: Beyond achievement to self-efficacy. Washington: American Psychological Association.

Zimmerman, B.J. (2008). Investigating self-regulation and motivation: Historical background, methodological developments and future prospects. American Educational Research Journal, 45(1), 166-183. 